\title{
Digital Tourism: A Content Analysis of West Java Tourism Websites
}

\author{
Fajar Kusnadi Kusumah Putra*, Pudin Saepudin, Edwin Adriansyah, I Gusti Agung Wahyu Adrian \\ Departement of Hotel Administration, Sekolah Tinggi Pariwisata NHI Bandung, Indonesia
}

\begin{abstract}
Digital tourism is one of three strategic priorities from Ministry of Tourism to increase the number of tourist who visiting Indonesia. Tourism industry is one of the successful sector using Internet media to share destination images, where the tourism websites becomes a very useful tool to promote tourism by giving important informations for visitors. This study explore the effectiveness of official tourism websites in West Java province, Indonesia. Content analysis method, consist of three dimension: Aesthetic (destination visualisation, websites design); Informative (uniqueness, monetery value, and cultural promotion); Interactive (e-travel planner, online communities) were used to asses 29 official cities and regency's tourism websites. The results presented within this paper showed that West Java tourism websites were found to be generally fair in one dimension but lacked to attracted visitors. Based on the result findings, it is recommended that the official tourism organisations should evolve their websites as the marketing tools and the most important for delivering positive images of the destination online. These research give implications for the local tourism websites administrator to improve the website's content and also further research in tourism websites evaluation.
\end{abstract}

Keywords: Content analysis, digital tourism, website's evaluation, west java tourism.

\section{INTRODUCTION}

As stated in Indonesia Government Work Plan 2017, Tourism is one of five priorities sector in 2017 for Indonesia's development, other sectors are food, energy, maritime, industrial estate, and Special Economic Zones. The development is in line with tourism sector as the Indonesia priority in National Medium-term Development Term (RPJM) 2015-2019. Tourism sectors become priority with an achievement target 20 million foreign visitors and 275 million domestic tourists in 2019. This sector in total will generate 260 trillion-rupiah [1].

Digital technology is one of the strategies in promoting Indonesia's tourism sector. This platform not only cheaper than the conventional way of promotion but also can reach more audiences both local and international. Development of digital facility directly expected to become a promotional channel to increase tourists visits, either in quality or quantity [2]. By using digital platform, the target audiance will be more personnel, more professional, and more global that directly provide accessibility for all tourism stakeholders in Indonesia.

Furthermore, digital technology will aslo help the local government to communicate their regulation but not limited in licensing aspect, tourism activity, and providing accessibility for the tourist in information to the destination in

${ }^{*}$ Correspondence address:

Fajar Kusnadi Kusumah Putra

Email : fap@stp-bandung.ac.id

Address : Sekolah Tinggi Pariwisata NHI Bandung,

Dr. Setiabudhi No. 186, Bandung, West Java 40141.
Indonesia [3]. According to The Travel and Tourism Competitiveness Report 2017 from 136 countries (Table 1), Indonesia has improved their position to $42^{\text {nd }}$ rank on the competitive index with powerful competitiveness performance in pricing area $\left(5^{\text {th }}\right)$, natural resources $\left(14^{\text {th }}\right)$, and prioritization of travel and tourism sector $\left(12^{\text {th }}\right)$. However, there are many aspects should be improved. One of the aspect is in Information and Communications Technology or ICT readiness that achieve $91^{\text {st }}$ rank [4].

In order to improve the global competitiveness index in Tourism, whe should prepare the ICT readiness. Indonesia should increase consistently in ICT sector, because tourism is one of the successful industries that use an Internet benefit where the quantity and online transaction value grown and has multiple effects through the economy $[5,6]$.

Internet has radically change the tourism and traveling sector. Internet users browse the internet to collect an information of traveling and has visit associated tourism destination website, finally create an impact to the economy development of the associated destination. Generally, internet has to support their user to gain a deal and product for a better value [6]. Request on website quality is unavoidable along with an increasing of Indonesia Internet user. For tourism business, demands on interesting website either in content and appearance is an important category for the society to create an intention to open and taking a benefit of the tourism business website and generating an e-commerce process $[7,8]$. 
Table 1. Indonesia ICT Readiness Competitive Index 2017

\begin{tabular}{lcc}
\hline \multicolumn{1}{c}{ Index Component } & Rank/136 & Score* \\
\hline \multicolumn{1}{c}{ ICT readiness } & $\mathbf{9 1}$ & $\mathbf{3 . 8}$ \\
\hline ICT use for biz-to-biz transactions & 58 & 4.8 \\
Internet use for biz-to-consumer transactions & 28 & 5.4 \\
Internet users \%pop. & 106 & 22.0 \\
Fixed-broadband Internet subscriptions /100 pop. & 107 & 1.1 \\
Mobile-cellular telephone subscriptions /100 pop. & 40 & 132.3 \\
Mobile-broadband subscriptions /100 pop. & 82 & 42.0 \\
Mobile network coverage \%pop. & 108 & 88 \\
Quality of electricity supply & 85.0 \\
\hline
\end{tabular}

Notes: ICT Scores [4], Scores are on a 1-to-7 scale unless indicated otherwise. For detailed definitions, sources, and periods, consult the interactive Country/Economy Profiles and Rankings at http://wef.ch/ttcr.

Research in hospitality and tourism sector has explained that the design of the website related to the marketing activities using Internet has effectively contribute in delivering the message, quality of the product and service, and business image [9]. According to the marketing aspect, the website development is not only one time practice, but regularly increase from the lower to the higher level of the website and create a functional and interactive aspect. As a result, the process can improve the website effectiveness. Tourism website should be designed in accordance with the organization vision, accommodate the requirement, including promoting the product information, also intention and expectation of the targetted market [10].

According to the previous researches, the online information is critical phase to plan a traveling process, currently buying behavior pattern strongly influences by the information from Internet media [11, 12]. In order to determined the tourism website, some researcher evaluates the website according to a comprehensive web content, quality, and website design where in this event, the site must be providing a clear information, accurate, and up -to- date $[13,14]$.

Some researchers in indonesia, explore the tourism websites by studying the domain for software application [15]. Comparison between accommodation website of five stars hotel using content-based aspect, and also tourism destination information content in tourism promotional official website $[16,17]$. Research on the website of tourism office within Top 10 priority destinations studied by the facilities and service's information approach that exist on the website [14].

The website of tourism destination will be a reference for online visitors. Therefore, the website should be user friendly by adapting standard features of tourism website and offering more up to date and comprehensive information about traveling to the related destination. The tourism website must have effective objection in enabling the visitors gathering a relevant information, navigating through various text and graphical element, and by creating first impression from the virtual way [18]. There are three phases related to the online information process: searching, advantage, and elaboration [19]. Most of the traveling planners prefer reading a review information from previous tourists review provided online rather than view the tourism brochure.

Effective tourism destination website should integrate the technology and marketing principle. The website should have an evaluation in the aspect of information, communication, transaction, user relationship, and technical service. Where the technical service directly influences effectiveness of others four marketing dimensions [20].

The tourism destination website must present an accurate information for the visitors in the level of marketing principle. After an appropriate implementation in information function, then the policy makers of the destinations must consider on the communication function and involve all marketing activity [20]. Moreover, the website enables the destination management in the local area to save their budget in printing and delivering the brochure and paper advertisement material, definitely support to decrease their limited promotional budget [21, 22].

There are three dimensions approach to measure tourism destination website effectiveness (Fig. 1), which are: Aesthetic dimension (AES) related on visitor accessibility of tourism destination website; Informative dimension (INF) on the quality of the tourism destination website; and Interactive dimension (INT) on the 
two directions guideline interaction for visitor, associated organization, community, and tourism business in related destination [23]. From these three dimensions, generated seven categories will clearly identified the aspect that really important for tourism website. The subcategories of aesthetic dimension are visualization of destination area and web design. The informative dimensions are a uniqueness factors of the website, the price range, and promotion of culture. The interactive dimensions include etravel guideline and online community [23].

The aims of this research are to analyze how far the quality of the tourism office website in each regency and city located in West Java province based on Aesthetic, Informative, and
Interactive dimension. There is no previous study related to in-depth research in measuring the tourism website content specifically in the scope of province destination area in Indonesia. Therefore, this research tries to answer some questions on condition in accessibility, interactive, and delivering an information to all parties of the society, from domestic to international tourist.

The result from this research will provide a suggestion to management parties of the tourism destination website related to actual condition. This research should explain a description and indepth information on the website development manage by tourism offices in West Java province.

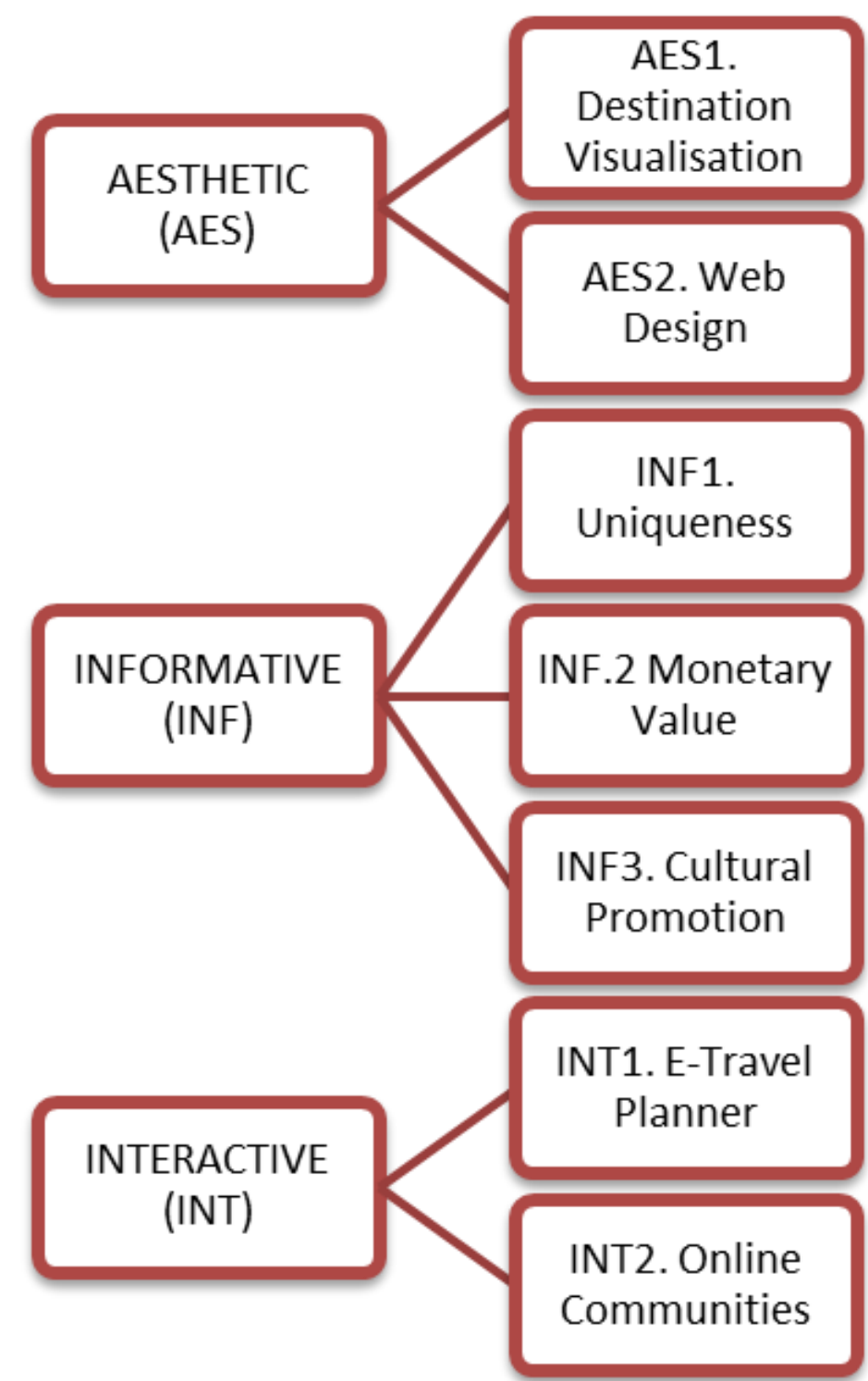

Figure 1. Dimensions and categories to measure tourism websites effectiveness [23]. Details in Supplementary 1. 


\section{RESEARCH METHOD}

According to content analysis, the researcher will observe the description of content, message characteristic, and the development of content. This method will systematically identify the visible content communication (manifest), and a practical objectives, valid, reliable, and replicable. The researchers in the content analysis in the tourism sector focus on the language communication selection and concentrated to the content and the context of the text. Textual data collection could be in verbal, virtual, or printing media. The data collection process is from descriptive narrative process, open-ended question survey, interview, focus group, observation, or through by the printing media [24].

Epistemologically, there are two categories in this research to analyze the content based on the social science: qualitative and quantitative approach. Qualitative approach is the nonstatistical and exploratory method involving inductive reasoning [25]. The quantitative approach refers to statistical conclusion method from the text population. The central idea of quantitative content is many words from the text are classified into much fewer content categories [26]. Quantitative content analysis of this research will evaluate the written communication and visual practice in the website of the regency and the city of tourism office in West Java province as communication media and promotional kit. Content analysis applied in this research because this method is a simple method to practice, effortless to continue for further study, and has remote possibility study without interfere the subject [27].

\section{Sampling and Data Collection Procedure}

The Ministry of Tourism has been offering many options of tourism office websites in 33 provinces of Indonesia as a research data. This study will focus on an evaluation of the tourism website in West Java province. The samples are 18 regencies and 10 cities in the administrative area of West Java province (Fig. 2).

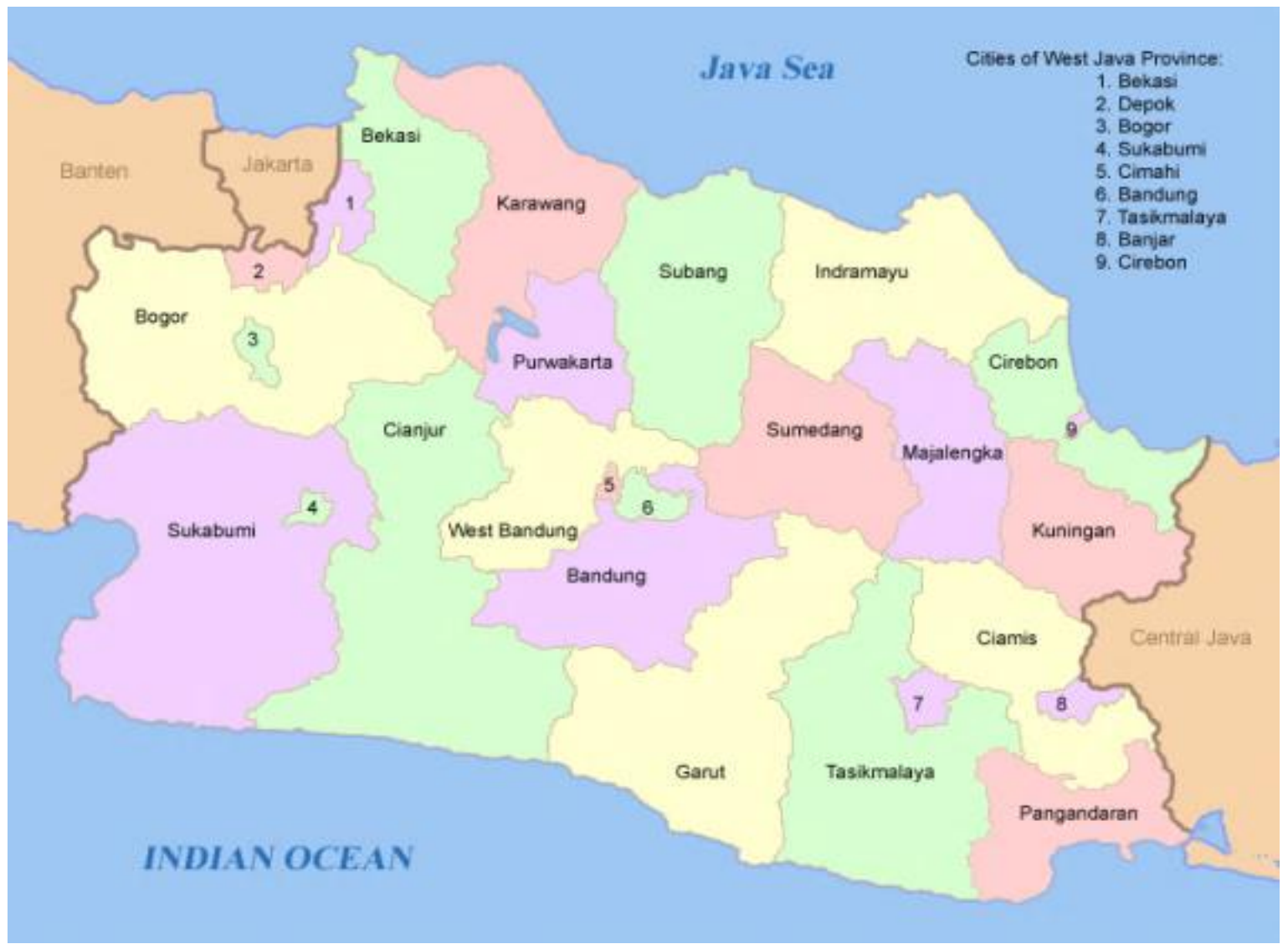

Figure 2. Administrative Map of West Java Province [4]. 
This research will observe 29 tourism websites in West Java, consists of one official website of West Java tourism office, 18 websites of regency tourism board, and 10 websites of city tourism office in the administrative area of West Java province. An initial observation was done to collect the website address information associated to tourism destination in West Java, which consists of one primary website of tourism office in West Java province, 18 tourism websites in regency level, and nine websites of tourism office in the city level of West Java province.

\section{Encoding the Website Content}

Three researchers with tourism background analyzed the tourism office website. The researchers spent two hours in training session; the researcher tries to encode some websites sampling. The final coding processed in the period of 2 months in 2017. The researcher that accepted the coding book and website URL lists requests to work independently to evaluate 29 websites of tourism office in West Java province.

The homepage of the target website (the first page displayed in the website) is the analysis unit of this research. The research objects are the reliable websites in terms of information quantity, navigation structure, and comprehensiveness (in number of secondary page information). Therefore, the main page of the website homepage encodes with content analysis method.

Furthermore, the researcher team developed a coding book with three variables, including seven categories and 47 indicators for this research [23]. Every website sign by the code number, 1 if the requirement content of all indicators is available, and 0 if the content of every indicators is not available. Pilot test study in West Java tourism main website is to examine the survey instrument. In order to evaluate the minimum and maximum score of every website involves in this research, and then creates a measurement to calculate the capability of websites in the seven categories of this research. Implementation of the survey instrument should be conducted completely for a website of tourism office before moving to another website [27].

There are seven categories with 45 different indicator's, value for each category in percentage (\%) are calculated by the number of indicators for each categories divide to the total number of indicators available for measuring tourism websites (Table 2). The first category is destina- tion visualization (AES1) this category will indicate the capability of the website to give the visitors an appealing background, the use of color and pictures, destination logo and slogan, video, newsletter, and online brochures. In this, category represents seven indicators or equal to $16 \%$ from total indicators. The second categories, web site design (AES2) will be measured how the tourism website has a clear text, uncluttered web page, easy to remember web address, table of contents, site map, home button, search navigation and latest update of the website represent $20 \%$ for all categories.

The third categories related to information uniqueness (INF1), which included specialized travel trips, using another languages, and sufficient for information for traveling represent $7 \%$ of the all categories. The fourth categories will give information for the visitors regarding the monetary value of the destination (INF2), included travel package's prices, hotel room rate, food and beverage price, transportation cost, special festivals and events price, and also an attraction admission fees represent $16 \%$ of the categories. The fifth categories related with the cultural promotion (INF3) represent $11 \%$ of all categories, included information about the tourism attraction and things to do on the destination, local weather, and insider tips from local authority, and culture information.

Table 2. Value of each category and Indicators number

\begin{tabular}{clcc}
\hline Dimensions & \multicolumn{1}{c}{ Categories } & $\begin{array}{c}\text { Value } \\
\text { (\%) }\end{array}$ & $\begin{array}{c}\text { Number of } \\
\text { Indicators }\end{array}$ \\
\hline \multirow{2}{*}{ Aesthetic } & $\begin{array}{l}\text { Destination } \\
\text { visualization }\end{array}$ & 16 & 7 \\
\cline { 2 - 4 } & Web Design & 20 & 9 \\
\hline \multirow{2}{*}{ Informative } & Uniqueness & 7 & 3 \\
\cline { 2 - 4 } & Monetary Value & 16 & 7 \\
\cline { 2 - 4 } & $\begin{array}{l}\text { Cultural } \\
\text { Promotion }\end{array}$ & 11 & 5 \\
\hline \multirow{2}{*}{ Interactive } & $\begin{array}{l}\text { E-Travel } \\
\text { Planner }\end{array}$ & 22 & 10 \\
\cline { 2 - 4 } & $\begin{array}{l}\text { Online } \\
\text { Communities }\end{array}$ & 9 & 4 \\
\hline & TOTAL & $\mathbf{1 0 0}$ & $\mathbf{4 5}$ \\
\hline
\end{tabular}

Source: Han and Mills [23].

The Sixth categories are related the function of the website, as an interactive media for the traveler to plan their trip the E-travel planners (INT1) are the most value categories in the tourism website evaluation covering $22 \%$ of all categories. On these categories included the information of hotel and other accommodation, information to local attraction, information of restaurant, link to travel agent, information on 
car rental on the destination, information about the events and festival reservation, contact information to non-tourism organization, and also maps on major attraction at the destination. The seventh category is related with the online communities (INT2) on the Frequently Asks Questions (FAQ) by the visitors, order free guide book online, subscription for news, newsletters and vacation deals are represent $9 \%$ of the total categories in tourism website evaluation.

Moreover, a guideline percentages range to supports the evaluation process of every website. The guideline has a function to determine a measurement of website competitiveness level with $51 \%$ value composition to $100 \%$ means has a good performance and as the highest category. The value $11-50 \%$ is average performance, and less than $10 \%$ are the lowest website performance.

\section{RESULT AND DISCUSSION}

Identification of 29 tourism websites of West Java province performs by searching activity to the official tourism websites. The list of websites found by Google search engine, each URL address was examined in detail. Initial observation found an information of an accessible website lists, under construction, inaccessible, and tourism office without an official website.

The website's evaluation measures the performance aspect of the websites by four approaches dimension of tourism website presentation, which is (I) aesthetic dimension (AES), (ii) informative dimension (INF), and (iii) interactive dimension (INT). This research focuses on the distinction and similarities of the website dimensions by evaluating the instrument designed for this research. Coding sheet generates from the guideline, and the result conclusion will have an in-depth analysis [23].

This section will discuss about content analysis results of the 29 tourism office websites in the regency and the city of West Java province. There are four discussion sections, which are content analysis in aesthetic, informative, attractive dimension, and the last section is a comprehensive analysis of the tourism office website in the regencies and cities of West Java province.

An initial searching found 29 websites of tourism office in the regency and the city of West Java province and only 20 websites are accessible. The reason why nine websites are inaccessible because the factor of: Sukabumi city has a tourism blog, not official websites. In addition, Karawang Regency, Cimahi City, and Banjar City do not have an official tourism website. Tasikmalaya Regency, Majalengka Regency, and Cirebon City tourism websites are under development or under maintenance. Under maintenance status of the website is regular activity of the website administrator to maintenance the website properly live. In this event, access to the website is inaccessible.

Moreover, Cianjur Regency and Tasikmalaya City websites are suspended. Suspended website has some factors, such as pending hosting payment, the overload server, or infringement to the Terms and Condition of the hosting service. Accessibility of the tourism official websites, made the further process only contain the analysis from 20 websites.

\section{Result of Aesthetics Dimension Content (AES)}

According to the content analysis in 20 websites of the regency and the city of West Java province, the average of all tourism office websites fulfills $82 \%$ or 16 from 20 indicators for aesthetic dimension requirement, related on visualization of tourism destination and design of the website.

\section{Destination Visualization (AES 1)}

The coding result from 20 tourism office websites in West Java in visualization aspects found that 19 tourism office websites applied a background, an appropriate color for visual appeal, and exposing the photos of their destination to improve the image of their area. Moreover, a short video description for local tourism area applied by 12 tourism websites.

Interestingly, every website such as Ciamis Regency display the background combines with an attractive flash player animation and presenting an eye-catching background, photo, and color. In addition, the West Java official tourism websites manage by West Java provincial government has been implementing the color combination of dark brown, gold, and green as a reflection of West Java.

Additional indicator such as bulletin media applied by 15 websites, while Kuningan Regency, Indramayu Regency, and Depok City does not have bulletin content for their website. Fewer indicators of every region in visualization category of destination are online brochure implementation and accessible for every website visitor. West Java provincial government, Sumedang Regency and Bandung City are not providing online brochure service. Appearances 
of logo or slogan in the website are not completely applied, only 12 websites displaying their local logo or slogan.

\section{Web design (AES 2)}

There are 20 tourism office websites applied clear and readable indicators; the indicator has a relationship with font type, contrast between background and text, and creating a clean and uncluttered page. Total 20 websites providing availability of Home button in the website homepage. Nineteen out of 20 websites have table of content, but this number is not proportional with search engine practice for website content. Only 18 websites have additional dimension. Cirebon Regency and Subang Regency do not apply this dimension to their website. This number will be declined if associated with another indicator related to browsing data in the website or the site map. Only 7 from 20 website have the sitemap for their visitor.

There are 19 websites continuously updating their local tourism data and providing latest updates of web page/update version as an indicator of information. This is the indication of an appropriate website management of the local area and responsibility in management indicator. Bandung Regency website is the only one website that does not provide to update information, the latest information is 2012.

Easy to remember indicators of the website address name were found on nine websites. The other's websites still practice a sub domain in the name of their area. Acronym usage of tourism office bases on the local area apparently infective because the domain is longer, and including a character that's hard to find by visitors. Examples of tourism office website address comparison: http://disparbud.kotabogor.go.id/ for Bogor City and Bandung city with http://www.bandungtourism.com/, where the Bandung City tourism website has an easy terminology to remember globally, by using the name of the city and English terminology.

\section{Result of Informative Dimension Content (INF)}

Performance in 17 of 20 websites in West Java area only limited in providing information in terms of a uniqueness; information of financial value of facility, price, and promotion; and cultural promotional categories in every tourism office are below level or $50 \%$. The average percentage is $38 \%$ or 6 of 15 indicators are available.

\section{Uniqueness (INF 1)}

Based on the content analysis of 20 website, each websites has a characteristic features in providing the information about specialize in travel trips to the feature destination and tourism attraction of every area. Total of 18 websites publish various destinations, such as Sumedang Regency website that highlight traveling to the local natural tour destination, from the mountain, jungle, river to the south of Java Sea. Kuningan Regency highlights traveling activity, especially to Geo park site and maritime tourism, such as surfing in their local area. Some websites have a proper order in tourism specific category of interest, for example the culinary tourism (Bandung City, Bogor City, Garut Regency).

Moreover, sufficient information content on travel guide to the area, consist of public transportation access, location data to the destination, and statistic of local tourism. The information is available to download from tourism office websites of the regency and city of West Java. The information is related to the egovernment function. One of the functions is providing data transparency to the public.

There are some important aspects should be improved from $75 \%$ of the website (15 websites) which are not providing availability of foreign language facility in presenting their website data. There are only five websites has been providing a support access for English language, Bandung City website, Sumedang Regency, Garut Regency, Cirebon Regency, and Ciamis Regency. Moreover, two websites provide option more than two languages, Sumedang Regency website with Indonesia, English, and Japanese. Ciamis Regency has nine languages option for their visitors, English, Germany, Spanish, Mandarin, Arabic, Russian, Italian, France, and Dutch.

\section{Monetary value (INF 2)}

Economical factor to calculate the process of tourism traveling activity is the price range of various aspects in the tourism destination. Every website in this category could provide a data about standard price of the infrastructure in the tourism destination. In this regard, $90 \%$ of tourism office websites in West Java province does not provide information of the price range for accommodation, restaurant, attraction, and tourism festival, local public transportation, and special price offer for the visitor when visiting to the destination. This condition certainly became 
a shortage for every area in promoting every business sector of local tourism.

There are four websites present an information about the range of prices on the hotels, from the various accommodation types in their local area, Bandung City, Bogor City, West Bandung Regency, and West Java province. In addition, two websites explain the information of standard price for package for the visitor candidate, and entry ticket for some tourism attraction or the price on other attractions). The number is getting smaller when we are describing information of price on public transportation and online special price. Two indicators, range prices of restaurant and range of prices on the festival held by the local tourism destination, as far as the complementation of this paper are not yet provided by the websites to be analyzed in this study.

\section{Cultural promotion (INF 3)}

The tourism official websites in West Java province has properly promoting activity in terms of the introducing native culture of Sundanese to the tourist candidate. In addition, in terms of information of well-known attraction, including things to do in the destination, the website has described proper information. Textual information is not only information but also the pictures of tourism attraction should be exhibited as part of promotional activity of the tourism destination.

Weather information should have improvement of the destination for the tourist. Only Seven websites have been displaying weather information. In addition, more important information is the regulation of the local area such as visa, customs and excise. More perspective of an essential information or insider tips are applied in six websites. Some interesting dimension is writing the experience when visiting the area on a media of the tourism office website of Bandung city. Websites of West Java provincial government, Bogor city, Garut regency, Bogor regency, and Pangandaran regency are also providing related information.

\section{Result on Interactive Dimension Content (INT)}

There are 8 of 20 websites has proper content, 12 websites should improve the feature to become more interactive for the visitor. Average total values of 20 websites are $55 \%$ or 8 of 14 categories are above the average.

\section{E-Travel planners (INT 1)}

Electronic travel planner content is the most indicators in this research, interactive information to support the visitor to plan their journey. Therefore, up to date on the related information of a destination is highly important. According to the factual analysis of this category, has been providing information / website link / contact information of tourism attraction of the area. Total 17 websites present an information content indicator of their event activity, booking for the special event of the local area, and contact information of National Tourism Organization (NTO).

Additionally, accommodation and restaurant list in the local expose in 13 websites of tourism office. The number will decrease when the category is associated with comprehensive information of hotel accommodation in terms of URL link or phone number; 11 websites provide this information. More information on local tourism attraction explains by 12 websites of tourism office, and 11 websites providing a guideline in form of the main tourism attraction map of the local area. This category should consider in the integration of the travel planner party, such as tour and travel agent, travel biro, and rental transportation service.

\section{Online communities (INT 2)}

Total of 14 tourism office websites provide an online subscription service for up to date information about the associated office. There are only 10 websites that provide Frequently Asks Questions or FAQ from the visitors.

Only 8 websites provide online travel consulting services. Contradict, none of the tourism websites in West Java province provide an online booking guideline for traveling of their local area to the visitors.

\section{Rank of the Websites}

The recapitulation result explained that the website of Bandung City tourism office is the first position in providing a facility for all categories in their website content, even the website only fulfills 37 of 45 total indicators (Table 3). Moreover, the lowest value is the website of Bekasi Regency with 13 indicators value of all informative indicators for tourism website.

The average of the tourism website for regency and city of West Java province is 27 or $59 \%$ information content of 45 ideal indicators of the tourism website. These numbers explain 20 websites of West Java province tourism have been presenting a proper information service. 
Table 3. Result from Content Analysis of 20 websites in West Java, 2017

\begin{tabular}{|c|c|c|c|c|c|c|c|c|c|}
\hline \multirow{3}{*}{$\begin{array}{c}\text { Name of Cities } \\
\text { \& Regencies }\end{array}$} & \multicolumn{2}{|c|}{ AESTHETICS (AES) } & \multicolumn{3}{|c|}{ INFORMATIVE (INF) } & \multicolumn{2}{|c|}{ INTERACTIVE (INT) } & \multirow{2}{*}{\multicolumn{2}{|c|}{$\begin{array}{c}3 \text { dimensions } \\
7 \text { Categories } \\
\text { (45 items ) }\end{array}$}} \\
\hline & $\begin{array}{c}\text { AES 1 } \\
\text { (7 items) }\end{array}$ & $\begin{array}{c}\text { AES 2 } \\
\text { (9 items) }\end{array}$ & $\begin{array}{c}\text { INF 1 } \\
\text { (3 items) }\end{array}$ & $\begin{array}{c}\text { INF 2 } \\
\text { (7 items) }\end{array}$ & $\begin{array}{c}\text { INF } 3 \\
\text { (5 items) } \\
\end{array}$ & $\begin{array}{c}\text { INT 1 } \\
\text { (10 items) }\end{array}$ & $\begin{array}{c}\text { INT } 2 \\
\text { (4 items) }\end{array}$ & & \\
\hline & \multicolumn{5}{|c|}{ Score (\%) } & & & Score & $\%$ \\
\hline Bandung City & 100 & 100 & 100 & 29 & 100 & 80 & 75 & $37 / 45$ & 82 \\
\hline Pangandaran Regency & 71 & 89 & 67 & 57 & 80 & 100 & 75 & $36 / 45$ & 80 \\
\hline West Java Province & 100 & 89 & 100 & 0 & 80 & 100 & 75 & $35 / 45$ & 78 \\
\hline Bogor City & 86 & 100 & 67 & 14 & 80 & 100 & 75 & 35 / 45 & 78 \\
\hline Garut Regency & 86 & 89 & 100 & 0 & 100 & 90 & 75 & $34 / 45$ & 76 \\
\hline Sumedang Regency & 100 & 89 & 67 & 0 & 80 & 80 & 75 & 32 / 45 & 71 \\
\hline Bandung Regency & 71 & 100 & 67 & 43 & 80 & 50 & 50 & $30 / 45$ & 67 \\
\hline Bogor Regency & 86 & 100 & 67 & 0 & 60 & 80 & 50 & $30 / 45$ & 67 \\
\hline Subang City & 71 & 100 & 67 & 0 & 60 & 60 & 25 & $26 / 45$ & 58 \\
\hline Cirebon Regency & 57 & 89 & 67 & 0 & 60 & 80 & 25 & $26 / 45$ & 58 \\
\hline Subang Regency & 57 & 100 & 67 & 0 & 80 & 50 & 50 & $26 / 45$ & 58 \\
\hline Kuningan Regency & 57 & 78 & 100 & 0 & 80 & 60 & 0 & $24 / 45$ & 53 \\
\hline Purwakarta Regency & 86 & 89 & 67 & 0 & 80 & 20 & 25 & $23 / 45$ & 51 \\
\hline Sukabumi Regency & 57 & 100 & 67 & 0 & 60 & 40 & 25 & $23 / 45$ & 51 \\
\hline Bekasi City & 71 & 89 & 67 & 0 & 40 & 40 & 50 & $23 / 45$ & 51 \\
\hline Bandung Barat Regency & 86 & 78 & 67 & 0 & 60 & 30 & 25 & $22 / 45$ & 49 \\
\hline Ciamis Regency & 57 & 89 & 100 & 0 & 60 & 30 & 25 & $22 / 45$ & 49 \\
\hline Depok City & 43 & 100 & 33 & 0 & 40 & 40 & 0 & $19 / 45$ & 42 \\
\hline Indramayu Regency & 43 & 89 & 0 & 0 & 20 & 30 & 0 & $15 / 45$ & 33 \\
\hline Bekasi Regency & 29 & 67 & 0 & 0 & 0 & 50 & 0 & $13 / 45$ & 29 \\
\hline
\end{tabular}

According to the result, eight websites of tourism office fulfill the information content and above of the average of all total websites of tourism offices in West Java. Moreover, the others 12 websites should improve their website content quality, especially in the monetary value (INF 2), cultural promotion (INF 3) from informative dimension, and an e-travel planner (INT 1) categories, and online communities (INT 2 ) in interactive category.

After measuring the value, then the percentage result produce in all websites, as presenting in the Table 3 . The top five websites of tourism office West Java province ranks with more than $75 \%$ percentage value are the Bandung City, Pangandaran Regency, West Java Province, Bogor City, and Garut Regency website. Moreover, 10 tourism office websites in 50\%74\% range are Sumedang Regency website, Bandung Regency, Bogor Regency, Subang City, Cirebon Regency, Subang Regency, Kuningan Regency, Purwakarta Regency, Sukabumi Regency, and Bekasi City. Five tourism websites of tourism office in $50 \%$ range value are West Bandung Regency, Ciamis Regency, Depok City, Bekasi Regency, and Indramayu Regency

\section{CONCLUSION}

Digital tourism will be providing accessibility to all tourism stakeholder in Indonesia, from licensing aspect, tourism activities and events, and presenting accessibility for the visitors to find information regarding the tourism destination in Indonesia. A functional, enlightened, and interesting website will force and facilitate the visitors to visit the tourism destination. The tourist will have more value to destination because of the collection of information in price and special promotion price for the tourist. In order to maintenance loyal visitors, an organization should open many opportunities to the destination by communicating to the visitor, exposing the advertisement of the destination, and increasing the level of customer involvement.

As the result, this condition creates a possibility to tourism destination management with the opportunity to improve the loyalty level of the customer. The result is not only beneficial for destination managements, but also providing an insight for the policy maker and tourism organization as the effort to promote their destination through the Internet media. Definitely, this information will become a support information on the website reliability of tourism office. In fact, the tourism website destination is an image representation of a country. Further study should examine a wider scope of the city and regency in Indonesia country region regarding the practice of the standardization of the tourism website.

\section{ACKNOWLEDGEMENT}

The authors would like to thank to the Ministry of Tourism, Republic of Indonesia through Research and Community Service Center (RCSC) Sekolah Tinggi Pariwisata NHI Bandung who has been funding this research. 


\section{REFERENCES}

[1] Khumaedy, M. A. 2017. Tahun 2017 Kita Genjot Sektor Pariwisata. Available at: http://setkab.go.id/tahun-2017-kitagenjot-sektor-pariwisata.

[2] Pitana, I G. and S. P. Putu-Diah. 2016. Digital marketing in tourism: the more global, the more personal. In: Wiranatha, A. S., I P. E. N. Kencana, I K. G. Bendesa, I N. D. Putra, I G A. O. Suryawardani (Eds). International Tourism Conference: Promoting Cultural and Heritage Tourism. Udayana University, Bali. 1-3 September 2016, 116-125.

[3] Noviyanti, S. 2014. E-Tourism: bentuk promosi pariwisata Indonesia selanjutnya. Kompas Travel, I Made Ashdiana (Eds.) Kompas Gramedia, Jakarta.

[4] Roberto-Crotti, T. M. 2017. The travel and tourism competitiveness report 2017: paving the way for a more sustainable and inclusive future. In: Roberto-Crotti, T.M. (Ed). 2017 World Economic Forum. Geneva.

[5] Buhalis, D. and R. Law. 2008. Progress in information technology and tourism management: 20 years on and 10 years after the internet-the state of eTourism research. Tourism Management 29(4), 609-623.

[6] Yuan, Y. L., U. Gretzel and D. R. Fesenmaier. 2003. Internet technology use by American convention and visitors bureaus. Journal of Travel Research 41(3), 240-255.

[7] Khudri, T. M. Y., D. Martani and T. I. Maulana. 2013. Analisis kualitas desain dan kunjungan situs pemerintah daerah di Indonesia. Proceeding of PESAT (Psikologi, Ekonomi, Sastra, Arsitektur dan Teknik Sipil) 5, E-40-E-49.

[8] Putra, F. K. K. 2017. Analisis informasi situs web hotel bintang 4 di kota Bandung. Tourism and Hospitality Essentials (THE) Journal 7(1), 7-20.

[9] Ting, P. H., C.F. Kuo and C. M. Li. 2012. What does Hotel Website Content Say About a Property: an evaluation of upscale hotels in Taiwan and China. Journal of Travel and Tourism Marketing 29(4), 369384.

[10] Sweeney, S. 2005. One hundred and one ways to promote your web site. Florida: Maximum Press.
[11] Law, R., S. Qi and D. Buhalis. 2010. Progress in tourism management: a review of website evaluation in tourism research. Tourism management 31(3), 297-313.

[12] Law, R. and B. Bai. 2008. How do the preferences of online buyers and browsers differ on the design and content of travel websites? International Journal of Contemporary Hospitality Management 20(4), 388-400.

[13] Zhou, Q. and R. DeSantis. Usability issues in city tourism Web site design: a content analysis. In: Hayhoe, G. (Ed). Proceedings of International Professional Communication Conference (IPCC 2005). IEEE (Institute of Electrical and Electronics Engineers). Limerick, Ireland. 10-15 July 2005, 789-796.

[14] Subandi, M. R. and F. K. K. Putra. 2017. Website evaluation for the local tourism offices of Indonesia's top 10 priority destinations. In: Amin, Md. R. (Ed). $1^{\text {st }}$ International Conference on Tourism. Department of Tourism and Hospitality Management, Faculty of Business Studies, University of Dhaka, Bangladesh. (n.a).

[15] Nurmi, N. 2017. Membangun Website Sistem Informasi Dinas Pariwisata. Jurnal Edik Informatika 1(2), 1-6.

[16] Adi, S. 2014. Evaluation on the effectiveness of the web technology usage in promoting and marketing Indonesia tourism. Journal of Theoretical and Applied Information Technology 68(3), 622 - 629.

[17] Sari, R. P. 2016. Analisis tingkat pengungkapan konten dari websites hotel bintang 5 di Indonesia. Jurnal Kajian Bahasa dan Pariwisata (BARISTA) 3(2), 223234.

[18] Palmer, A. and P. Mc Cole. 2000. The role of electronic commerce in creating virtual tourism destination marketing organizations. International Journal of Contemporary Hospitality Management 12(3), 198-204.

[19] Kim, H. and D. R. Fesenmaier. 2008. Persuasive design of destination web sites: An analysis of first impression. Journal of Travel research 47(1), 3-13.

[20] Li, X. and Y. Wang. 2010. Evaluating the effectiveness of destination marketing organisations' websites: Evidence from China. International Journal of Tourism Research 12(5), 536-549.

[21] Feng, R., A. M. Morrison and J. A. Ismail. 2004. East versus West: a comparison of 
online destination marketing in China and the USA. Journal of Vacation Marketing 10(1), 43-56.

[22] Gretzel, U., D. R. Fesenmaier, S. Formica and J. T. O'Leary. 2006. Searching for the future: challenges faced by destination marketing organizations. Journal of Travel Research 45(2), 116-126.

[23] Han, J. H. and J. E. Mills. 2006. Zero acquaintance benchmarking at travel destination websites: what is the first impression that national tourism organizations try to make? International Journal of Tourism Research 8(6), 405-430.

[24] Berg, B. L. 2004. Methods for the social sciences: qualitative research methods for the social sciences. Pearson Education. Boston.

[25] Weber, R. P. 1990. Basic content analysis, $2^{\text {nd }}$ Ed. Sage Publication. California.

[26] Barreda, A. and A. Bilgihan. 2013. An analysis of user-generated content for hotel experiences. Journal of Hospitality and Tourism Technology 4(3), 263-280.

[27] Millar, M. and G. Sammons. 2006. A content analysis of Costa Rican ecolodge Websites. The University Of San Francisco. San Francisco. 
Supplementary 1. Table Dimensions, Categories, Indicators for Content Analysis in Tourism Websites

\begin{tabular}{|c|c|c|}
\hline DIMENSIONS & CATEGORIES & INDICATORS \\
\hline$\overline{\text { AESTHETIC }}$ & AES1. Destination & AES1.1. Aesthetically appealing background; \\
\hline \multirow[t]{15}{*}{ (AES) } & Visualisation & AES1.2. Use of colour to improve the visual appeal of the site; \\
\hline & & AES1.3. Use of pictures to enhance the aesthetics of the destination; \\
\hline & & AES1.4. Destination logo/slogan; \\
\hline & & AES1.5. Availability of online video clips (virtual tour); \\
\hline & & AES1.6. Availability of online newsletters; \\
\hline & & AES1.7. Availability of online brochures. \\
\hline & AES2. Web Design & AES2.1. Clear and readable text; \\
\hline & & AES2.2. Clean and uncluttered page; \\
\hline & & AES2.3. Sufficient contrast between background and text; \\
\hline & & AES2.4. Easy to remember Web address; \\
\hline & & AES2.5. Table of contents; \\
\hline & & AES2.6. Site map; \\
\hline & & AES2.7. Availability of 'home' button; \\
\hline & & AES2.8. Search engine for website content; \\
\hline & & AES2.9. Late update of Web page (date of the last updated version). \\
\hline \multirow[t]{15}{*}{$\begin{array}{l}\text { INFORMATIVE } \\
\text { (INF) }\end{array}$} & INF1. Uniqueness & $\begin{array}{l}\text { INF1.1. Specialised travel trips - e.g. families, convention, food, experience } \\
\text { culture, sporting events, etc.; }\end{array}$ \\
\hline & & INF1.2. Availability of foreign language; \\
\hline & & INF1.3. Sufficient (adequate) information on trips or travel. \\
\hline & INF.2 Monetary Value & INF2.1. Standard price for packages; \\
\hline & & INF2.2. Online special prices; \\
\hline & & INF2.3. The range of price on restaurants; \\
\hline & & INF2.4. The range of prices on hotels; \\
\hline & & INF2.5. The range of prices on public transportation; \\
\hline & & INF2.6. The range of prices on festivals; \\
\hline & & INF2.7. The range of prices on other attractions. \\
\hline & INF3. Cultural Promotion & INF3.1. Information on well-known attractions; \\
\hline & & INF3.2. Local weather information; \\
\hline & & INF3.3. Things to do; \\
\hline & & INF3.4. Essential information (visa, custom, etc.) or insider tips; \\
\hline & & INF3.5. Introduction of the culture. \\
\hline \multirow{13}{*}{$\begin{array}{l}\text { INTERACTIVE } \\
\text { (INT) }\end{array}$} & INT1. E-Travel Planner & INT1.1. Link or contact information to hotels/accommodations; \\
\hline & & INT1.2. Links or contact information to local attractions; \\
\hline & & INT1.3. List of accommodations; \\
\hline & & INT1.4. List of restaurants; \\
\hline & & INT1.5. Link or contact information to online travel agent/agency; \\
\hline & & INT1.6. Information/link/contact information on rent-a-car; \\
\hline & & INT1.7. Information/link/contact information on other attractions e.g. museum; \\
\hline & & INT1.8. Information/link/contact information on events and festival reservations; \\
\hline & & $\begin{array}{l}\text { INT1.9. Contact information of NTO; } \\
\text { INT1.10. Maps of major attractions; }\end{array}$ \\
\hline & INT2. Online & INT2.1 Availability of online community (FAQ); \\
\hline & Communities & INT2.2 Order (free) guide book (pamphlet); \\
\hline & & INT2.3 Online travel board; \\
\hline & & INT2.4. Online subscription for news, vacation deals or newsletters. \\
\hline
\end{tabular}

Adapted from: Han and Mills [23]. 